\title{
Interim Qualification Tests and Procedures for Terrestrial Photovoltaic Thin-Film Flat-Plate Modules
}

R. DeBlasio
L. Mrig
D. Waddington

January 1990

Prepared under Task No. PV020601

Solar Energy Research Institute

A Division of Midwest Research Institute

1617 Cole Boulevard

Golden, Colorado 80401-3393

Prepared for the

U.S. Department of Energy

Contract No. DE-AC02-83CH10093 


\section{NOTICE}

This report was prepared as an account of work sponsored by an agency of the United States government. Neither the United States government nor any agency thereof, nor any of their employees, makes any warranty, express or implied, or assumes any legal liability or responsibility for the accuracy, completeness, or usefulness of any information, apparatus, product, or process disclosed, or represents that its use would not infringe privately owned rights. Reference herein to any specific commercial product, process, or service by trade name, trademark, manufacturer, or otherwise does not necessarily constitute or imply its endorsement, recommendation, or favoring by the United States government or any agency thereof. The views and opinions of authors expressed herein do not necessarily state or reflect those of the United States government or any agency thereof.

Printed in the United States of America

Available from:

National Technical Information Service

U.S. Department of Commerce

5285 Port Royal Road

Springfield, VA 22161

Price: Microfiche A01

Printed Copy A03

Codes are used for pricing all publications. The code is determined by the number of pages in the publication. Information pertaining to the pricing codes can be found in the current issue of the following publications which are generally available in most libraries: Energy Research Abstracts (ERA); Government Reports Announcements and Index (GRA and I): Scientific and Technical Abstract Reports (STAR): and publication NTIS-PR-360 available from NTIS at the above address. 
PREFACE

This document has been prepared in response to the expressed concerns and general consensus of photovoltaic community participants attending the SERI/DOEsponsored PV Thin-Film Module Reliability Testing and Evaluation Workshop, held in Lakewood, Colorado, on August 13-14, 1987 [1]. It provides interim qualification screening tests and procedures to primarily evaluate new terrestrial photovoltaic thin-film flat-plate modules intended for power generation applications. The term "interim" is used because thin-film module design and cell material technologies are undergoing evolutionary changes in their development; therefore, the information contained in this document will be updated as needs arise.

The primary intent of this document is to provide the minimum tests and inspections required to evaluate photovoltaic thin-film flat-plate modules and to provide a common approach (e.g., between producer and purchaser) in conducting qualification tests. With the tests and procedures provided in this document, additional tests and procedures, beyond the test sequences specified, may be established between the producer and purchaser that represent current procurement practices. This document is strictly intended for thinfilm photovoltaic cell material technologies and module (flat-plate) designs and does not include in its scope cell materials and module designs commonly referred to as thick-film modules (e.g., crystalline silicon) or concentrator modules.

Currently, existing thin-film flat-plate module designs are under development, and new concepts continue to appear. This requires that qualification tests be flexible enough to allow a reasonable assessment of new designs, yet complete enough to identify weaknesses that would lead to problems in the field. Ideally, modules that experience early failures in field operation should fail qualification tests. Therefore, it is important to note that the design of this document and the tests specified were developed as stated above, on an interim basis, and are not intended at this time to serve as a uniform standard for the thin-film flat-plate module photovoltaic industry.

The effort to manage and coordinate the development of this document was assigned to SERI by the U.S. Department of Energy in association with the Jet Propulsion Laboratory and Sandia National Laboratories. Inquiries concerning details of the document or requests for additional information should be directed to R. DeBlasio, L. Mrig, or D. Waddington at SERI.

The authors wish to express appreciation for the manuscript review and helpful suggestions provided by the photovoltaic community at large, with special thanks to William Bottenberg (ARCO Solar Inc.), Joseph Burdick (ECD/Sovonics), Robert D'Aiello (Solarex Corp.), Madeleine Johnson (Chronar Corp.), Ronald Ross (Jet Propulsion Laboratory), Michael Stern (Utility Power Group), Walt Stolte (Bechtel National Inc.), and Michael Thomas (Sandia National Laboratories) for assisting in the development and detailed reviews of initial draft manuscripts. 
TABLE OF CONTENTS

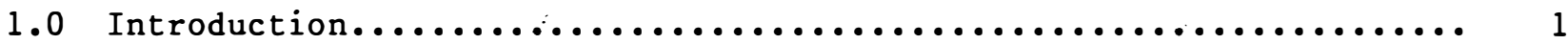

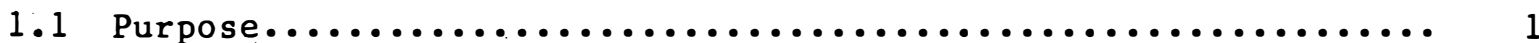

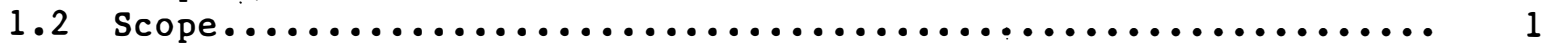

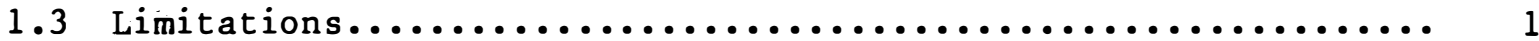

2.0 Background and Overview of Qualification Test ............... 2

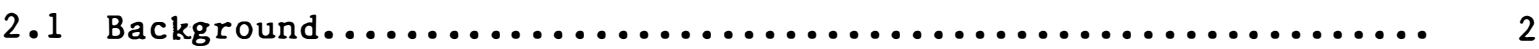

2.2 Overview of Qualification Test....................... 2

3.0 Module Test and Evaluation Requirements.................... 4

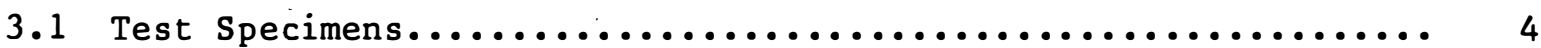

3.2 Initial Tests and Inspections............................ 4

3.2.1 Baseline Visual Inspection....................... 4

3.2.2 Baseline Electrical-Performance Test................ 4

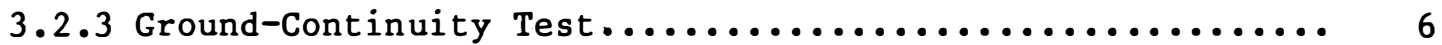

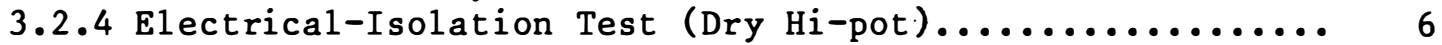

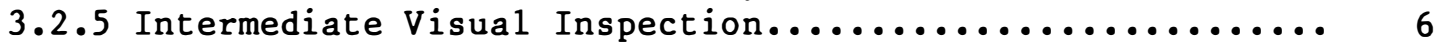

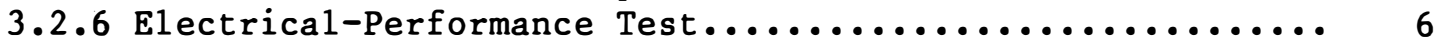

3.3 Completion of Initial Tests and Inspections............... 6

3.4 Sequence "A" Tests and Inspections...................... 6

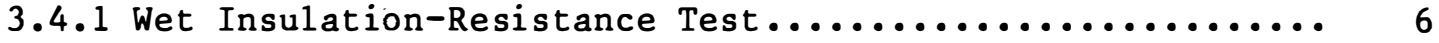

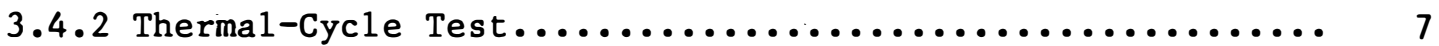

3.4.3 Humidity-Freeze Cycle Test........................... 7

3.4.4 Mechanical-Loading Test.......................... 7

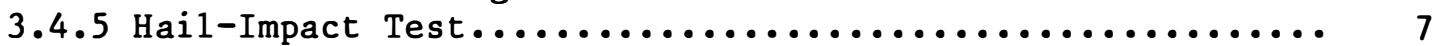

3.4.6 Surface-Cut Susceptibility Test...................... 7

3.4.7 Wet Insulation-Resistance Test................... 7

3.5 Sequence "B" Tests................................... 8

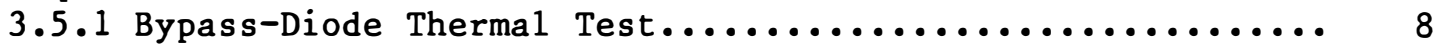

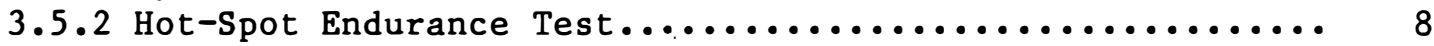

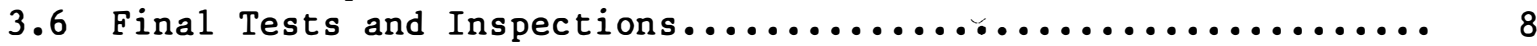

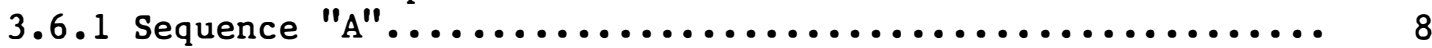

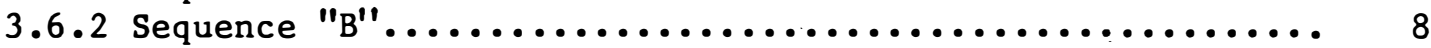

3.7 Evaluation of Qualification-Test Results................ 8

4.0 Module Test and Inspection Procedures...................... 10

4.1 Visual-Inspection Procedure........................ 10

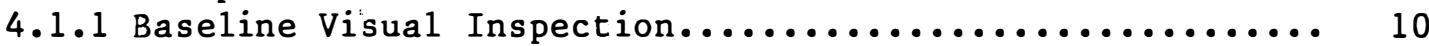

4.1 .2 Intermediate Visual Inspections.................... 10

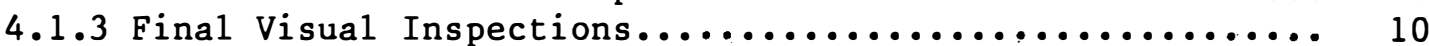

4.2 Electrical-Performance Test......................... 11

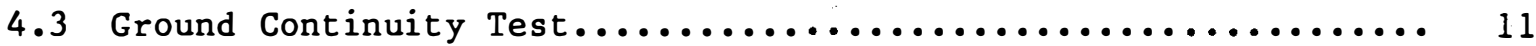

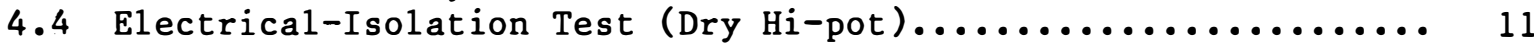

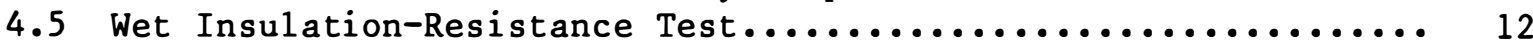

4.6 Thermal-Cycle Test................................. 13 
TABLE OF CONTENTS (Concluded)

$\underline{\text { Page }}$

4.7 Humidity-Freeze Cycle Test.......................... 14

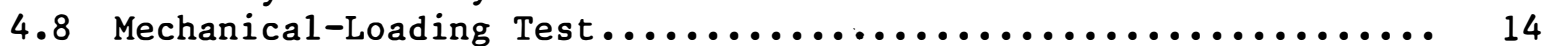

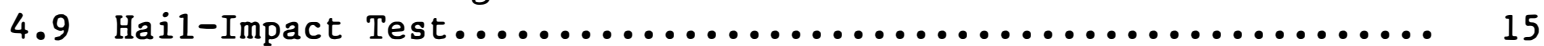

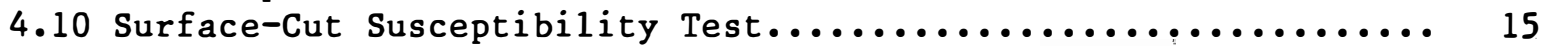

4.11 Electrical-Isolation Test (Wet Hi-pot)...................... 15

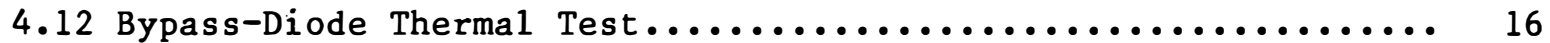

4.13 Hot-Spot Endurance Test............................ 18

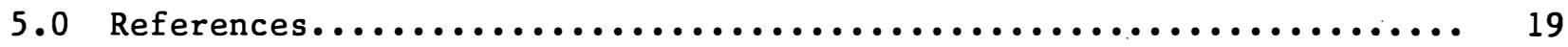

Appendix A Hot-Spot Endurance Test Procedure for Thin-Film Modules...... A-1 


\section{LIST OF FIGURES}

Page

3-1 Qualification Test Sequence........................... 5

4-1 Module Temperature Variation During the Thermal-Cycle Test........ 13

4-2 Module Temperature Variation During the Humidity-Freeze Cycle Test.. 14

4-3 Test Circuit for Measuring Bypass-Diode Junction Temperature....... 17

A-1 Typical Reverse-Voltage I-V Plot for a Sample of Cells........... A-2

A-2 Effect of Test Cell Illumination Level on Hot-Spot Power

Dissipation..................................... A 4 
SECTION 1.0

INTRODUCTION

\subsection{Purpose}

The purpose of the qualification tests provided in this document are to evaluate flat-plate thin-film photovoltaic (PV) module design performance and susceptibility to known failure mechanisms. Emphasis is placed on testing and evaluating module performance characteristics and design features that will affect possible degradation of module performance and physical properties resulting from solar exposure, environmental weathering, mechanical loading, corrosion, and module shadowing.

\subsection{Scope}

This document establishes recommended procedures and specifications for qualification tests that are structured to evaluate terrestrial thin-film flatplate photovoltaic nonconcentrating modules intended for power generation applications [2].

\subsection{Limitations}

Because of limited thin-film module field operation experience and the evolutionary nature of new thin-film module material technologies and designs, the tests provided in this document should not be considered definitive or complete at this time, nor do they provide a basis for predicting 30-year life in the field (PV system goal). Current understanding of failure and degradation mechanisms and the relationship between accelerated tests and field reliability is not sufficient to allow accurate estimation of life-expectancy, nor are the cycling tests given in this document considered. to be equivalent to a full 30-year field exposure. However, the test and evaluation procedures given in this document provide a common approach for conducting qualification tests. Acceptable results from these tests should provide reasonable assurance that the modules that pass these tests will perform reliably in the field but for an unspecified period of time. In addition, characterization tests to determine module energy rating, and tests to evaluate the effects on module performance due to combined $\mathrm{UV} /$ thermal environments and light-induced degradation, as well as the design of a non-intrusive hot-spot test method, are currently under development and are not included in this document. This document will be revised in the future to incorporate the latest information on failure mechanisms and the relationships between accelerated tests and field reliability. 
SECTION 2.0

\section{BACKGROUND AND OVERVIEW OF QUALIFICATION TEST}

\subsection{Background}

In developing this qualification-test document, several sources of information were referenced and utilized in designing and formulating the majority of the tests given. Primary sources included the Jet Propulsion Laboratory (JPL) Block $V$ specification for flat-plate modules [3] and the Underwriters Laboratories standard for flat-plate modules [4]. Since the publication of these documents, photovoltaic thin-film materials technology and module development have advanced rapidly. Major efforts by the photovoltaic industry, JPL, and SERI in module reliability research have produced a better understanding of known and potential failure mechanisms associated with thin-film modules, especially with regard to the effects of moisture ingress.

The results of these efforts and experience gained have been utilized in formulating new tests and modifying earlier tests for inclusion in this document. For example, one modification includes an increase in the humidity-freeze test cycle from 10 to 20 cycles to accelerate the potential for moisture-ingressinduced effects on performance and safety. Also included are new tests for wet insulation resistance and surface-cut susceptibility, which further represent an increased focus on identifying water-ingress-induced failures and electrical-shock hazard.

\subsection{Overview of Qualification Test}

The overall qualification test is designed to minimize the time to conduct the required tests and the number of test module specimens. A minimum of six test modules is required to complete all the specified tests. The qualificationtest sequence is illustrated in Figure $3-1$, and the required test and inspection procedures are provided in Section 4.0. Module qualification test requirements, which provide detailed guidance and minimum requirements for conducting the overall qualification test, are given in Section 3.0. Test and evaluation requirements provided in section 3.0 include (1) initial tests and inspections, (2) sequence " $A$ " and " $B$ " tests and inspections, (3) final tests and inspections, and (4) evaluation of qualification test results.

Initial tests and inspections (Section 3.2) establish selection and acceptance of as-received modules as test module specimens. They also establish baseline visual-inspection information and electrical-performance measurement data for comparison and determination of the effects on module physical characteristics and electrical performance following exposure and endurance tests.

Sequence "A" tests and inspections (Section 3.4) include a variety of environmental and stress tests designed to induce and identify failure mechanisms that may lead to module failure, degraded electrical performance, physical deformities, or shock hazard. Sequence "B" tests (Section 3.5) include a bypass-diode thermal test to assess the thermal design adequacy of bypass diodes, if used in the module construction, and a hot-spot endurance test to determine the long-term effects of module hot-spot heating associated with a condition such as shadowing. 
The final tests and inspections (Section 3.6) establish a final database for comparison with initial test and inspection results.

The criteria for passing the qualification tests are provided in Section 3.7 (Evaluation of Qualification Test Results). 


\section{SECTION 3.0}

\section{MODULE TEST AND EVALUATION REQUIREMENTS}

This section specifies the minimum tests and inspections to be performed and the required test sequence to be followed to evaluate photovoltaic thin-film flat-plate modules. The required test sequence is illustrated in the flow diagram provided in Figure 3-1 along with designated inspection and test identification numbers corresponding to inspections and test procedures specified in Section 4.0 .

\subsection{Test Specimens}

A minimum of six module test specimens of each module type representative of the modules to be deployed in the field is required to conduct all the tests specified in this document. One test module required for the hot-spot endurance test shall be specially fabricated with leads brought out for accessing individual cells as specified in Appendix A.

The baseline power output determined in accordance with Section 3.2.2 for each of the six modules shall be within $\pm 10 \%$ of the average power output of modules proposed or planned for field deployment.

Each module test specimen shall have a serial number or label or some other means of identification capable of surviving both test sequences.

Selection and acceptance of as-received modules as module test specimens shall be based on passing the initial inspections and tests specified in Section 3.2 and in the sequence shown in Figure 3-1 and meeting the power output uniformity requirement specified above. Any module design or fabrication changes (e.g., materials, manufacturing process, or assembly) of a module type previously tested and evaluated may require reevaluation and testing. Such determination may be made between the module producer and purchaser of the modules.

\subsection{Initial Tests and Inspections}

Initial tests and inspections shall be performed in the order described below and as illustrated in Figure 3-1.

\subsubsection{Baseline Visual Inspection}

Each module shall be visually inspected in accordance with the specifications given in Section 4.1.1 to obtain a baseline determination of the presence or absence of defects in the module for purposes of detecting any changes after each required test.

\subsubsection{Baseline Electrica1-Performance Test}

Each module shall be measured in accordance with the specifications given in Section 4.2 to establish a baseline electrical-output power that will serve as the comparison value for determination of the effects of qualification testing on electrical performance. 


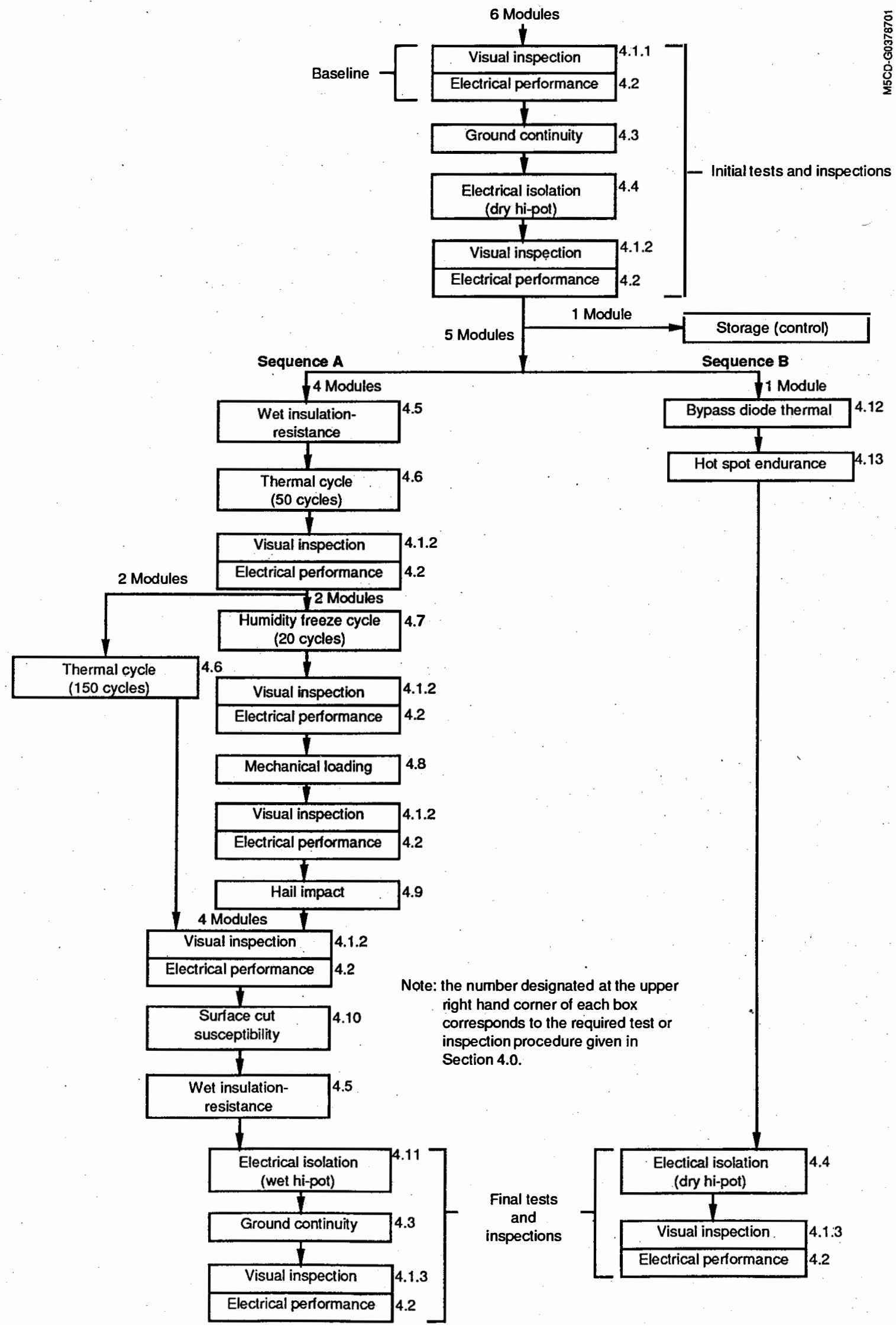

Figure 3-1. Qualification Test Sequence 


\subsubsection{Ground-Continuity Test}

Each module having exposed external conductive surfaces (i.e., frame, structural members, or edge closures) shall be tested in accordance with the specifications given in Section 4.3 to verify that continuity exists between all such surfaces and the module grounding point. Modules that use direct attachment to an array structure to obtain grounding shall be tested after assembly.

\subsubsection{Electrical-Isolation Test (Dry Hi-pot)}

Each module shall be subjected to a direct current (DC) hi-pot test in accordance with the specifications given in Section 4.4 to assure electrical isolation of the PV circuit from externally exposed conductive parts.

\subsubsection{Intermediate Visual Inspection}

Each module shall be visually. inspected in accordance with the specifications given in Section 4.1.2.

\subsubsection{Electrical-Performance Test}

Each module shall be measured in accordance with the specifications given in Section 4.2. The maximum power measured for each module tested shall not be less than $90 \%$ of the initial (measured) baseline power as determined in Section 3.2.2.

\subsection{Completion of Initial Tests and Inspections}

Each of the six module test specimens must meet the requirements specified in Sections 3.1 and 3.2 before testing can proceed. When these requirements are met, one of the modules shall be stored in the dark at room temperature to serve as a control module for future reference and until all planned tests have been completed. The remaining five modules shall be allocated for Sequence "A" and Sequence "B" tests and inspections as follows: four modules for conducting Sequence " $A$ " tests and inspections, as specified in Section 3.4, and one module for conducting Sequence " $B$ " tests, as specified in Section 3.5 .

\subsection{Sequence "A" Tests and Inspections}

The four modules selected for Sequence "A" tests shall be subjected to the following tests, which are described in detail in Section 4.0, and shall be conducted in the order indicated below and illustrated in Figure 3-1. Module intermediate visual inspections, in accordance with Section 3.2.5, and electrical-performance tests, in accordance with Section 3.2.6, shall be conducted after each applicable test as indicated in Figure 3-1.

\subsubsection{Wet Insulation-Resistance Test}

Sequence " $A$ " modules shall be tested to evaluate each module's electricalinsulation system by measuring the electrical resistance between the module circuitry and the frame or mounting surface in accordance with section 4.5 . 


\subsubsection{Thermal-Cycle Test}

The four modules selected for Sequence " $A$ " shall be subjected to the thermalcycle test in accordance with the specifications given in Section 4.6. At the end of 50 thermal cycles, the test shall be stopped, and visual inspections and electrical-performance tests shall be performed on all four modules. After these procedures are completed successfully, two modules shall be used for conducting the humidity-freeze cycle test (Section 3.4.3), and the other two modules shall undergo an additional 150 thermal cycles of exposure. At the completion of an additional 150 cycles, these two modules shall undergo visual inspection and an electrical-performance test. When successfully completed, these two modules shall be used in conducting the surface-cut susceptibility test (Section 3.4.6).

\subsubsection{Humidity-Freeze Cycle Test}

The two modules allocated for the humidity-freeze cycle test, following the 50-cycle thermal test, shall be tested in accordance with the specifications given in Section 4.7. At the completion of this test, visual inspections and electrical-performance tests shall be conducted on both modules. After these tests are completed successfully, the two modules shall be used in conducting the mechanical-loading test (Section 3.4.4).

\subsubsection{Mechanical-Loading Test}

The two modules allocated for the mechanical-loading test shall be tested in accordance with the specifications given in Section 4.8. At the completion of this test, a visual inspection and an electrical-performance test shall be conducted on both modules. When successfully completed, the two modules shall be used in conducting the hail-impact test (Section 3.4.5).

\subsubsection{Hail-Impact Test}

The two modules allocated for the hail-impact test shall be tested in accordance with the specifications given in Section 4.9. At the completion of this test, visual inspections and electrical-performance tests shall be conducted on both modules. Next, the two modules shall be used in conducting the surface-cut susceptibility test (Section 3.4.6), if required (see Section 4.10 for applicability of test).

\subsubsection{Surface-Cut Susceptibility Test}

The four modules (two modules following the 200-cycle thermal test and two modules following the hail-impact test) allocated for the surface-cut susceptibility test shall be tested, if required, in accordance with the specifications given in Section 4.10. When the test is successfully completed or when it is determined to be not applicable, the four modules shall be used in conducting the wet insulation-resistance test (Section 3.4.7).

\subsubsection{Wet Insulation-Resistance Test}

The four modules allocated for the wet insulation-resistance test shall be tested in accordance with the specifications given in Section 4.5. When this 
test is successfully completed, the four modules shall be used in conducting the final tests and inspections specified in Section 3.6 .1 for Sequence "A."

\subsection{Sequence "B" Tests}

The module selected for Sequence "B" tests shall be subjected to the following tests which are described in detail in section 4.0. The tests shall be conducted in the order indicated below and illustrated in Figure 3-1.

\subsubsection{Bypass-Diode Thermal Test}

The module allocated for the bypass-diode thermal test shall be tested in accordance with the specifications given in Section 4.12. When the test is successfully completed or when it is determined to be not applicable, the module shall be used in conducting the hot-spot endurance test (Section 3.5.2).

\subsubsection{Hot-Spot Endurance Test}

The module allocated for the hot-spot endurance test shall be tested in accordance with the specifications given in Section 4.13. After this test is successfully completed, the module shall be used in conducting the final tests and inspections specified in Section 3.6.2 for Sequence "B."

\subsection{Final Tests and Inspections}

At the completion of all the Sequence " $A$ " and Sequence "B" tests and inspections, the following final tests and inspections shall be conducted in the order indicated below.

\section{6:1 Sequence "A"}

Following the wet insulation-resistance test, the four modules allocated for the final tests and inspections shall be subjected to the electrical isolation test (wet hi-pot) in accordance with the specifications given in Section 4.11, followed by a ground-continuity test in accordance with section 3.2 .3 and a final visual inspection and electrical performance test in accordance with Sections 4.1 .3 and 3.2 .6 .

\subsubsection{Sequence "B"}

The module allocated for final tests and inspections, following the hot-spot endurance test, shall be subjected to an electrical-isolation test (dry hipot) in accordance with the specifications given in Section 4.4, followed by a final visual inspection and electrical-performance test in accordance with Sections 4.1 .3 and 3.2 .6 .

\subsection{Evaluation of Qualification-Test Results}

The criteria for passing the qualification tests are that each module, as allocated, must pass all of the following:

- initial tests and inspections (Sections $3.1,3.2$, and 3.3), 
- sequence "A" and sequence "B" tests and inspections (Sections 3.4 and 3.5),

- final tests and inspections (Section 3.6). 


\section{SECTION 4.0}

\section{MODULE TEST AND INSPECTION PROCEDURES}

The following module test and inspection procedures provide the detailed steps and specifications required to conduct and meet the overall qualification test requirements given in Section 3.0. Each of the following procedures provides a purpose for the test or inspection, detailed steps and specifications for conducting the test or inspection, and criteria for passing each test or inspection when criteria are not specified in Section 3.0 .

\subsection{Visual-Inspection Procedure}

The purpose of this procedure is to provide guidelines in obtaining baseline, intermediate, and final visual-inspection information required to identify and determine any physical changes or defects in module construction at the beginning and after the completion of each required test as specified in Section 3.0 .

\subsubsection{Baseline Visual Inspection}

Modules shall be photographed and visually inspected for good workmanship, shipping damage, mechanical mounting dimensions, and other inspection criteria established between the module producer and the purchaser of the module.

Any observed defects or abnormalities, such as minor flaws, delaminations or inclusions, scratches, or color that might adversely affect module performance or reliability shall be documented with appropriate sketches or photographs to show the location of the defects.

Information obtained above shall be well documented and formulated for use in comparing baseline observations with the results of all intermediate and final inspections, and for use in establishing a sound basis in determining the effects on module physical characteristics following each test.

Serious damage or defects are a basis for a module to be rejected without further testing.

\subsubsection{Intermediate Visual Inspections}

After each required test, the modules shall be visually inspected. Observations regarding damage or degradation observed during inspections shall be documented for comparison with baseline inspection results. The focus of inspection should be on forms of damage or degradation expected after each test. Any change in the module's physical appearance shall be documented in the same detail required for baseline inspection.

\subsubsection{Final Visual Inspections}

Modules shall be thoroughly inspected and photographed after testing. Any damage, degradation, or abnormalities that might affect long-term reliability shall be documented. Observations regarding damage or degradation observed during baseline and intermediate inspections shall be included with the documentation for the final inspection. 
Because of the wide variety of possible module designs, detailed visual inspection acceptance criteria are not provided in this document. Detailed inspection acceptance criteria shall be developed between the module manufacturer and the module purchaser. Application of the agreed-upon criteria will rely heavily on the expertise and engineering judgment of the inspectors and on their evaluation and comparison of intermediate and final visualinspection results with baseline inspection results.

\subsection{Electrical-Performance Test}

The purpose of this test is to characterize the electrical performance of test modules and to determine each module's peak output power.

The electrical-performance test is the measurement of data to plot an I-V curve from short-circuit current to open-circuit voltage with a minimum of 30 data points. All electrical-performance measurements shall be conducted in accordance with the following standard test and reporting conditions: AM 1.5 global solar reference spectrum as provided in ASTM E892 [5], total illumination intensity of $1000 \mathrm{~W} / \mathrm{m}^{2}\left(100 \mathrm{~mW} / \mathrm{cm}^{2}\right)$ and module temperature of $25^{\circ} \mathrm{C}$, using recommended ASTM measurement procedures as outlined in ASTM E1036 [6].

\subsection{Ground-Continuity Test}

Each module having exposed external conductive surfaces (i.e., frame, structural members, or edge enclosures) shall be tested to verify that electrical continuity exists between all such surfaces and the module frame or grounding point. Modules that use direct attachment to the array structure to obtain grounding shall be tested after assembly to a suitable simulated panel and array mounting frame. A current of twice the short-circuit current rating of the module shall be applied between the grounding point and each accessible conductive part under test. The resistance shall be computed by measuring the voltage drop between the grounding point and a point on the conductive surface within $12.7 \mathrm{~mm}(0.5 \mathrm{in}$.$) of the point of current injection. The resistance$ shall be $0.1 \mathrm{ohm}$ or less.

\subsection{Electrical-Isolation Test (Dry Hi-pot)}

The purpose of this test is to ensure electrical isolation of the PV circuit from any externally exposed conductive parts.

Each test module shall be subjected to both positive and negative polarity DC hi-pot testing conducted at room temperature with the output terminations short-circuited. Test leads from a suitable DC-voltage power supply shall be connected to the shorted terminals and the module grounding point. In the case of modules not provided with an equipment grounding stud, a conductive foil in contact with the entire insulated surface of the module shall be used as the alternate test point. Voltage shall be applied at a rate not to exceed $500 \mathrm{~V} / \mathrm{s}$ up to the test voltage of two times the system voltage plus $1000 \mathrm{~V}$ DC and held at this voltage for 1 minute. (Note: maximum system voltage anticipated for system applications for the modules being tested should be provided by the module producer or user.) 
The module shall be observed during the test and there shall be no signs of arcing or flash-over. DC-leakage current shall be monitored during the test and shall not exceed $50 \mu \mathrm{A}$. (Note: Based on tests conducted on thin-film modules, the leakage current for this test should be much lower than the $50 \mu \mathrm{A}$ criterion; experience has shown that the requisite wet insulation-resistance and wet hi-pot tests are more severe than the dry hi-pot test.) AC-leakage current resulting from power supply ripple and DC current resulting from capacitive charging shall not be considered. DC-leakage current during the test shall be recorded for each polarity.

\subsection{Wet Insulation-Resistance Test}

The purpose of this test is to evaluate the module's electrical insulation system under wet operating conditions and to verify that moisture caused by rain, fog, dew, or melted snow will not enter the active portions of the module circuitry, where it may cause corrosion, ground faults, or pose an electrical safety hazard to personnel.

The module is tested by immersing each edge in turn in a water/wetting agent (surfactant) solution*. The resistivity of the solution shall be $3500 \mathrm{ohm}-\mathrm{cm}$ or less and the surface tension of the solution due to the wetting agent shall be 30 dynes $/ \mathrm{cm}$ or less. The temperature of the module and the solution shall be $22 \pm 3^{\circ} \mathrm{C}$.

The insulation resistance is measured between the shorted output terminations and the solution by applying a voltage of $500 \mathrm{~V}$ DC (such as a Megger) in each polarity.

The test procedure is as follows:

Apply the test voltage and record the wet insulation resistance after 2 min for each edge of the module. Immerse the side with the lowest wet insulation resistance, apply the test voltage, and thoroughly wet all exposed surfaces of the module for approximately $10 \mathrm{~s}$, particularly the electrical-termination area, using a handheld spray containing the same solution. Record the insulation resistance reading after $2 \mathrm{~min}$. (Note: All wiring connections should be representative of the recommended field wiring installation; ensure that leakage currents are not originating from any instrumentation wiring attached to the module. Terminations and terminal boxes shall be maintained at least $12.7 \mathrm{~mm}$ ( 0.5 in.) above the solution level but shall be thoroughly wetted with the spray.) All resistance measurements shall exceed 100 megohms as measured with a suitable high-impedance ohmmeter (Megohmmeter or Megger).

*Surfactants such as Triton X-100 (Rohm and Haas Company) or its equivalent may be used for this test. A $0.1 \%$ solution of Triton $X-100$ in tap water is currently being used. (Tests conducted at JPL have indicated that a surface tension of 30 dynes/cm provides adequate wetting conditions.) The module should be thoroughly rinsed after the test. 


\subsection{Thermal-Cycle Test}

The purpose of the thermal cycle test is to determine whether test modules have adequate resistance to failure resulting from differential thermal expansion of component parts and bonding materials.

Test modules shall be subjected to the thermal cycles in accordance with the profile illustrated in Figure 4-1 showing the module temperature varying between $-40^{\circ} \mathrm{C}$ and $90^{\circ} \mathrm{C}$. The temperature shall vary approximately linearly with time at a rate not exceeding $120^{\circ} \mathrm{C} / \mathrm{h}$ and with a period not greater than $6 \mathrm{~h} / \mathrm{cycle}$. The modules shall be instrumented and monitored throughout the test to detect any open circuits or ground faults during the test. The modules shall not have exhibited either of these conditions during the test. Precautions should be taken to avoid condensation on the specimen during the test. (Note: An air vent through a container of silica gel will aid in reducing moisture concentration in the environmental test chamber.)

At the end of 50 cycles, the test shall be stopped and visual inspection and electrical-performance tests shall be performed on all four modules in accordance with Sections 3.2 .5 and 3.2 .6 , respectively. If all modules pass, two modules shall be transferred to the humidity-freeze cycle test as shown in the test sequence (Figure 3-1), and the remaining two modules shall undergo an additional 150 thermal cycles of exposure.

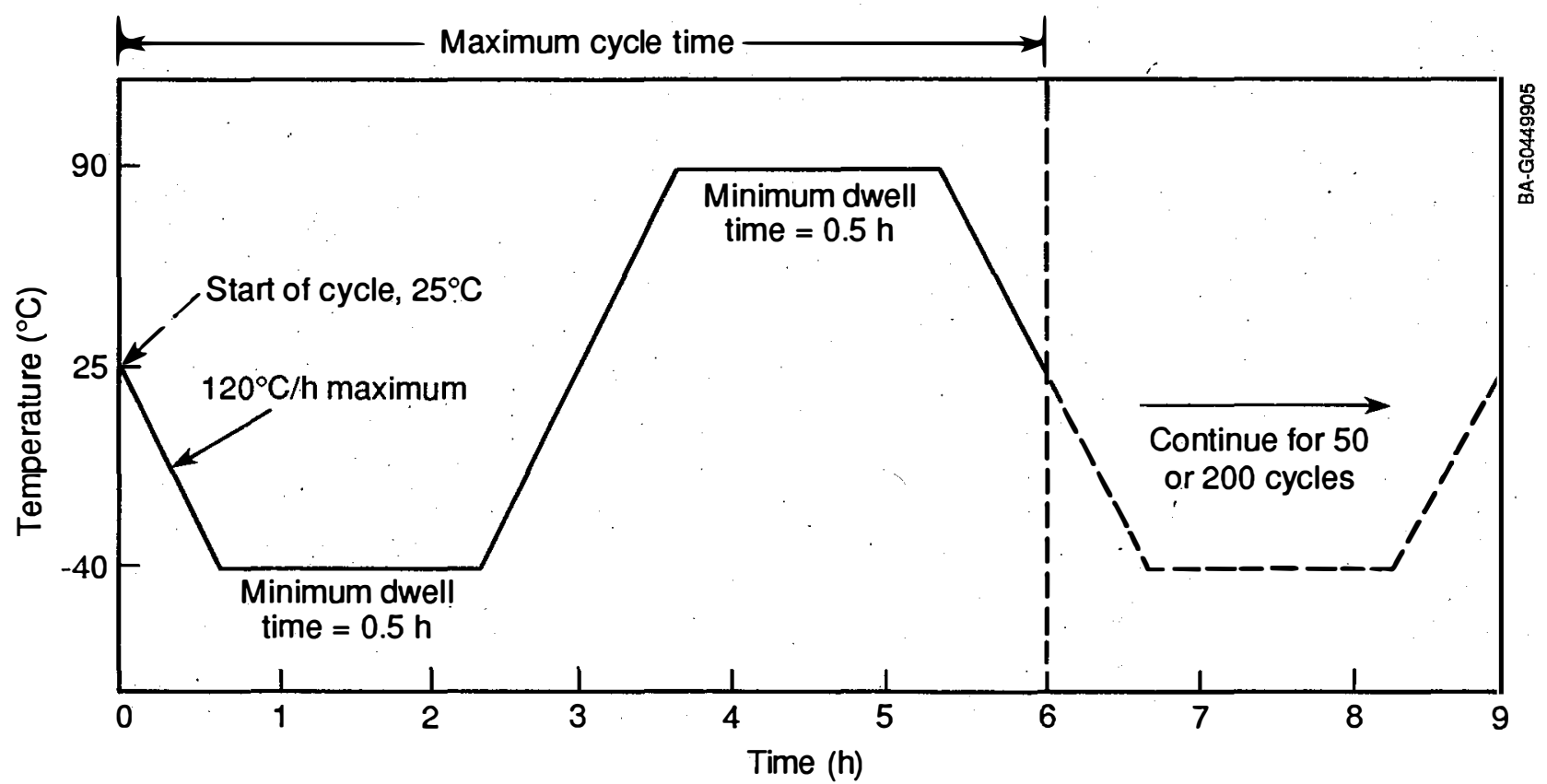

Figure 4-1. Module Temperature Variation During the Thermal Cycle Test (A shorter cycle time is acceptable if $120^{\circ} \mathrm{C} / \mathrm{h}$ maximum time is not exceeded. The Chamber may be opened at 25-cycle intervals for visual inspection.) 


\subsection{Humidity-Freeze Cycle Test}

The purpose of the humidity-freeze cycle test is to determine whether test modules have adequate resistance to the detrimental effects of humidity, condensation, and freezing and the resultant humidity-induced expansion of component materials.

Test modules shall be subjected to the humidity-freeze cycle test in accordance with the profile illustrated in Figure 4-2 showing that the humidity is controlled to $85 \pm 2.5 \%$ relative when the temperature is $85^{\circ} \mathrm{C}$ and allowed to saturate and condense at lower temperatures. The modules shall be instrumented and monitored throughout the test to detect any open circuits or ground faults during the test. The modules shall not have exhibited either of these conditions during the test. Twenty cycles shall be performed.

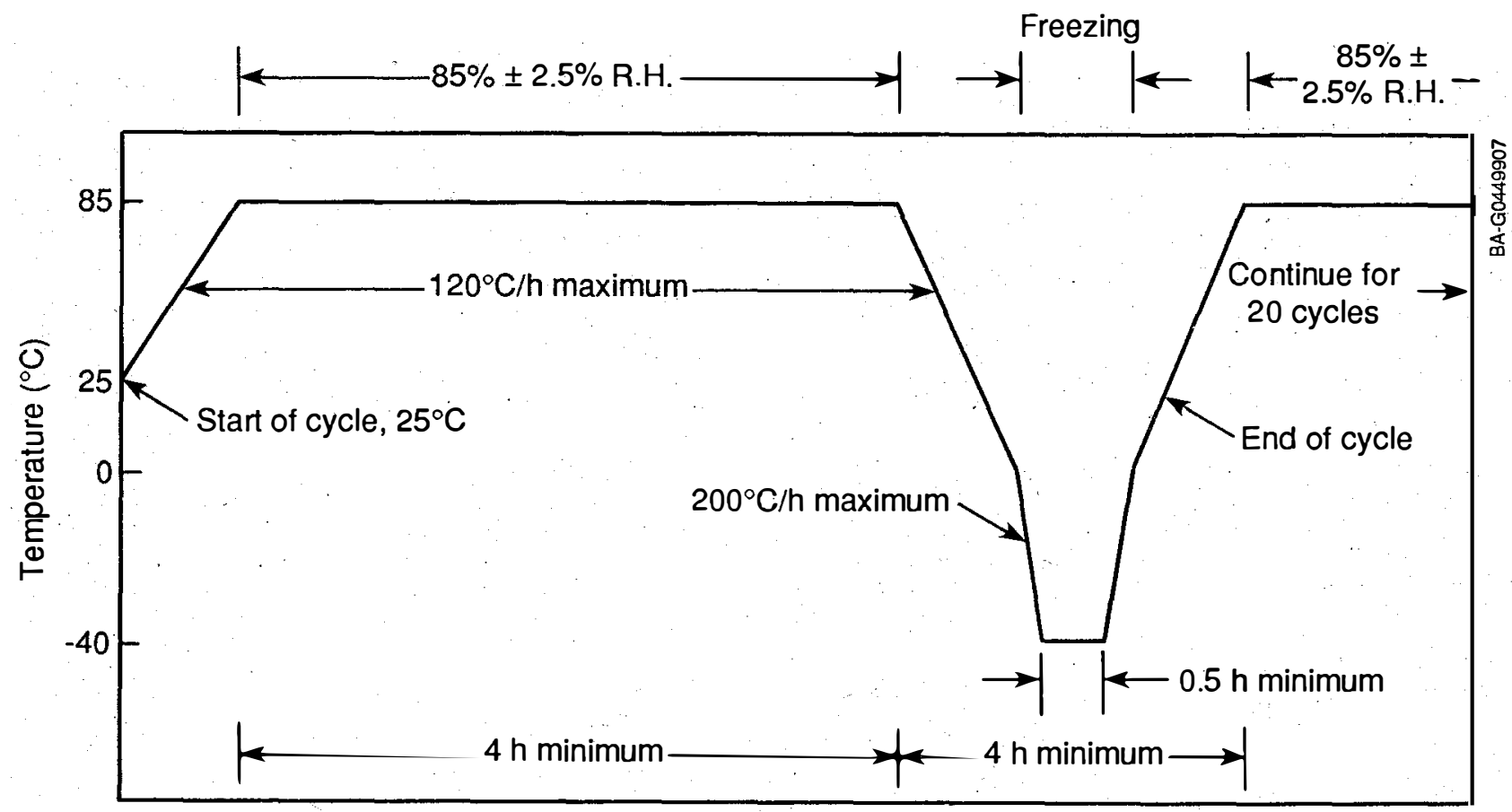

Time (h)

Figure 4-2. Module Temperature Variation During the Humidity-Freeze Cycle Test

\subsection{Mechanical-Loading Test}

The purpose of this test is to ensure that the test modules can withstand a wind gust loading of $301 \mathrm{~b} / \mathrm{ft}^{2}$. Modules shall be subjected to a dynamic wind loading test using 10,000 cycles of front and back surface loading with a load of $30 \mathrm{bb} / \mathrm{ft}^{2}$ according to UL Standard 1703, Section 38 [4] and Cyclic Pressure-Load Developmental Testing for Solar Panels, JPL 5101-19 [7]. The cycle rate shall not exceed 20 cycles/min.

The modules shall be instrumented and monitored throughout the test to detect any open circuits or ground faults during the test. The modules shall not have exhibited either of these conditions during the test. 


\subsection{Hai1-Impact Test}

The purpose of this test is to assess damage (if any) to the test module after a simulated hail impact. The modules shall be subjected to normal impact loading with $25.4-\mathrm{mm}$ (1-in.) diameter ice balls traveling at a terminal velocity of $23.2 \mathrm{~m} / \mathrm{s}(52 \mathrm{mph})$.

At least 10 of the test modules' most sensitive points shall be selected for impact. The candidate points selected should include (where applicable) the following:

- center points of cells.

o corners and edges of the module.

- point(s) directly near bypass diode(s), if installed.

- soldered or bonded metallic interconnects between cells, if present.

Errors of up to $13 \mathrm{~mm}(0.5 \mathrm{in.})$ in the location of a hit are acceptable. Either pneumatic or spring-actuated guns for projecting the ice balls against the modules are acceptable. Ice-ball velocity at impact must be controlled to within $\pm 5 \%$ of the specified velocity, and the required hailstone deviation in diameter shall be less than $\pm 3 \mathrm{~mm}$ ( 0.125 in.). The ice balls shall be cooled to $-10 \pm 2^{\circ} \mathrm{C}$ as measured in the compartment where they are stored. The module shall be supported in a manner representative of that used for actual installation of the module in the array. Note that ice balls are the only acceptable hailstone simulation. Steel balls, for example, shall not be used. Resistance of Photovoltaic Solar Panels to Simulated Hail, JPL 5101-62 [8], describes techniques and equipment suitable for performance of this test.

\subsection{Surface-Cut Susceptibility Test}

The purpose of this test is to ensure that the test modules shall be capable of withstanding the application of a sharp object drawn across its nonglass surfaces (front and back) without creating a risk of electrical shock.

Nonglass exterior surfaces of the module shall be subjected to the cut test described in paragraphs 23.1 through 23.3 of UL Standard 1703 [4]. Drawing of the tool illustrated on page 21 of the UL Standard 1703 shall be as described in paragraph 23.2 except that three passes shall be made across each surface and at least two of these passes shall be over the tops of grid lines, cell edges, cell interconnects, bus bars, and similar nonhomogeneous areas.

A risk of electric shock exists if the blade of the tool contacts a part involving a risk of electric shock or if such a part is rendered accessible (transitory or permanent) as a result of the placement of the blade on or the drawing of the blade across the surface.

\subsection{Electrical-Isolation Test (Wet Hi-pot)}

The purpose of this test is to ensure electrical isolation of the PV circuit from any externally exposed conductive parts when the module is wet.

This test shall be performed by dipping each edge of the test module into a wetting agent and water solution in a trough. The solution used for this test 
shall be the same solution used in the wet insulation-resistance test. The connection or junction box, if any, shall not be submerged. The front and back of the module shall be sprayed with the wetting solution (Note: The module shall be thoroughly wet). A voltage equal to twice the system voltage plus $1000 \mathrm{~V}$ DC shall be applied at a rate not to exceed $500 \mathrm{~V} / \mathrm{s}$ up to the test voltage and then held at the required test voltage for 1 minute in each polarity between the shorted leads of the module and the metal frame of the module. In the case of a plastic frame or no frame, the applied voltage shall be between the shorted terminals and an aluminum foil wrapped around the submerged edge of the test module or a metal plate submerged in the liquid. Each module edge, shall be submerged in the liquid in turn and the test repeated.

The module shall be observed during the test, and there shall be no signs of arcing or flash-over. The leakage current shall be less than $50 \mu \mathrm{A}$.

\subsection{Bypass-Diode Thermal Test}

The purpose of this test is to assess the thermal design adequacy and relative long-term reliability of bypass diodes used to limit the detrimental effects of module hot-spot susceptibility.

This test $1 \mathrm{~s}$ required only if bypass diode(s) are part of the module construction.

The procedure is based on measuring the diode's junction temperature, in situ, in its undisturbed proposed field mounting configuration, using the diode's forward-voltage-drop-versus-temperature as the measuring parameter. It consists of (1) establishing the diode's characteristic curve (voltage drop versus junction temperature); (2) measuring the diode junction voltage drop under simulated $125 \mathrm{~mW} / \mathrm{cm}^{2}, 40^{\circ} \mathrm{C}$ ambient conditions; and (3) converting the voltage drop to the junction temperature using the established characteristic curve.

The test procedure consists of the following three steps in the order given:

(1) Determine the diode forward-voltage drop versus junction-temperature characteristic curve for a chosen constant measurement current by placing the module/diode assembly in an oven. After achieving temperature stability of the diode junction, measure the diode forward-voltage drops at three oven temperatures (approximately 40,70 , and $100^{\circ} \mathrm{C}$ ). The measurement current $\mathrm{I}_{\mathrm{m}}$ (typically 50 to $100 \mathrm{~mA}$ ), should be selected to provide a good 1 inear response with temperature (i.e., not to heat the junction significantly) and be at least two orders of magnitude above module leakage current (with PV cells in darkness). Once selected, $I_{m}$ must be kept identical ( $\pm 1 \%$ ) for all junctionvoltage measurements. This is most easily implemented using an accurate constant-current power supply.

Accurately measure the temperature of the module/diode assembly (at the actual time the voltage measurement is made) using a thermocouple attached in the proximity of the diode. However, do not disturb the thermal/mechanical properties of the diode or its heat-transfer paths. 
Plot the measured temperature of the module/diode thermocouple against the diode junction voltage; a linear response should be achieved.

(2) Determine the diode junction voltage drop by covering the module to prevent illumination of the solar cells, or otherwise prevent photovoltaically generated voltages and currents from being impressed on the bypass diode. Using an infrared (IR) radiant heater, heat the normally sunlit surface of the module or diode mount to $35^{\circ} \mathrm{C}$ above room temperature; this simulates the typical temperature rise above ambient associated with an irradiance level of $100 \mathrm{~mW} / \mathrm{cm}^{2}$. After the module and diode reach thermal equilibrium, apply a test current to the diode equal to 1.25 times the short-circuit current of the module at $100 \mathrm{~mW} / \mathrm{cm}^{2}$ irradiance. Maintain the IR heating during the current application.

After the diode reaches thermal equilibrium (approximately $0.5 \mathrm{~h}$ for diodes integral to the module), instantaneously $(<0.5 \mathrm{~s})$ replace the test current $\left(1.25 \times I_{s c}\right)$ with. $I_{m}$ and immediately measure the diode forward voltage drop. Figure 4- 3 shows the test circuit for measuring the bypass-diode voltage drop. (Note: voltage and current instrumentation should provide accuracy to three or four places; use a fast-acting switch to remove the high test current and pass $I_{m}$ through the diode.)

(3) Determine the diode junction temperature $\mathrm{T}_{j}$ under $1.25 \mathrm{I}$ c current conditions using the curve established in step 1 , and adjust $T_{j}^{\text {sc }}$ from the previous step to correct for an ambient temperature of $40^{\circ} \mathrm{C}$ by using:

$$
\mathrm{T}_{\mathrm{j}}\left(125 \mathrm{~mW} / \mathrm{cm}^{2}, 40^{\circ} \mathrm{C}\right)=\mathrm{T}_{\mathrm{j}}+40^{\circ} \mathrm{C}-\mathrm{T}_{\text {room }}
$$

This is the expected diode junction temperature under $125 \mathrm{~mW} / \mathrm{cm}^{2}, 40^{\circ} \mathrm{C}$ ambient field conditions.

The pass/fail criterion for this test is that the diode junction temperature computed using Equation 1 should not exceed $125^{\circ} \mathrm{C}$ for $\mathrm{p}-\mathrm{n}$ silicon diodes or $75^{\circ} \mathrm{C}$ for Schottky diodes.

Sample-and-hold voltmeter

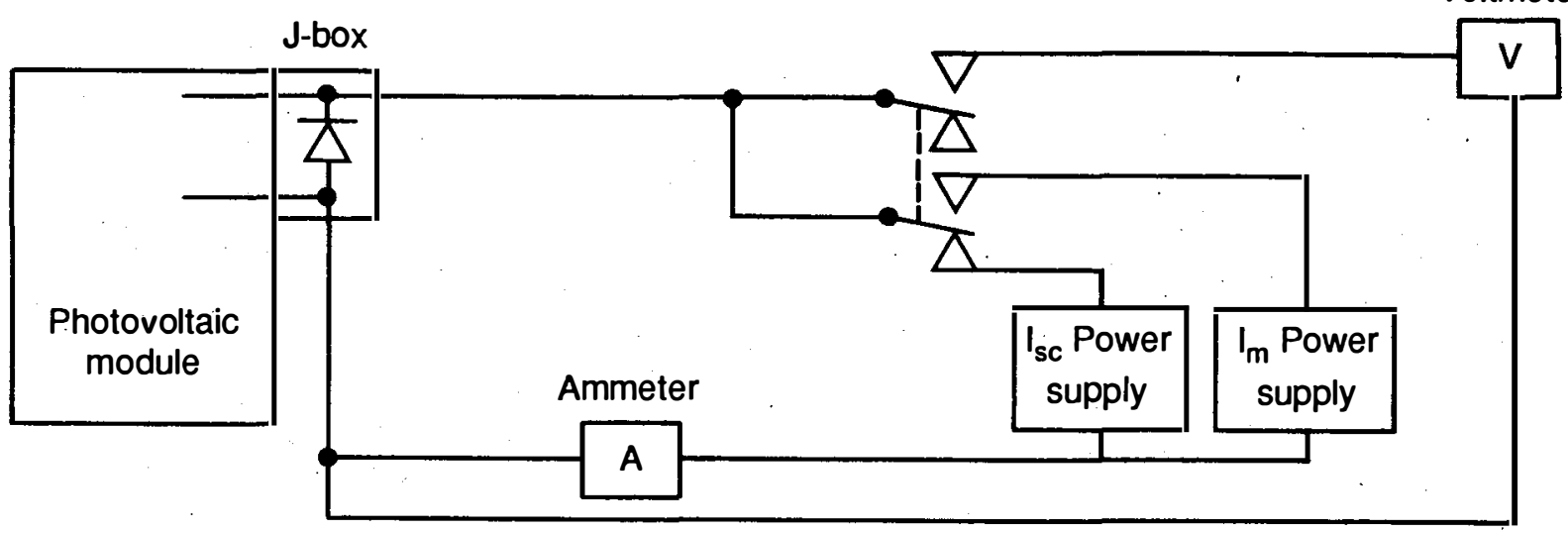

Figure 4-3. Test Circuit for Measuring Bypass-Diode Junction Temperature 


\subsection{Hot-Spot Endurance Test}

The purpose of this test is to evaluate the ability of a module to endure the long-term effects of periodic hot-spot heating associated with common fault conditions such as severely cracked or mismatched cells, single-point open circuit failures, or nonuniform shadowing (partial shadowing).

The test module as allocated in Section 3.5 .2 shall undergo the hot-spot endurance test as described in Appendix A. This approach is "intrusive" in nature and thus requires the fabrication of a specially built test module with leads brought out for accessing individual cells.

The module is considered to have passed the hot-spot endurance test if at the completion of this test, there is no visible damage to the the module. Evidence of degradation (including delamination, outgassing or blistering of encapsulants), cell cracking, solder melting, or other defects resulting from this test should be identified. If module damage should occur, a diode or more diodes per series string may be required to mitigate the hot-spot heating effect.

A nonintrusive hot-spot endurance test is currently under development by the International Electrotechnical Commission (IEC), PV Energy Systems Technical Committee TC-82. When adopted and published by the IEC, this approach will be evaluated and considered for inclusion in the revised version of this document as an alternate to the intrusive approach described in Appendix A. 


\section{SECTION 5.0}

\section{REFERENCES}

1. Photovoltaic Thin Film Module Reliability Testing and Evaluation Workshop, August 13-14, 1987, Lakewood, Colorado, SERI/CP-275-3239, Golden, CO: Solar Energy Research Institute.

2. x IEEE Recommended Criteria for Terrestrial Photovoltaic Power Systems. ANSI/IEEE Standard 928-1986, New York: The Institute of Electrical and Electronics Engineers (IEEE).

3. $x$ Block V Solar Cell Module Design and Test Specification for Intermediate Load Applications, 1981, JPL 5101-161, Pasadena, CA: Jet Propulsion Laboratory.

4. x Underwriter's Laboratories Inc., August 1, 1986, Standard for Safety for Flat-Plate Photovoltaic Modules and Panels, UL Standard 1703.

5. x Terrestrial Solar Spectral Irradiance Tables at Air Mass 1.5 for a $37^{\circ}$ Tilted Surface, ASTM Standard E892, New York: American Society of Testing and Materials.

6.x Electrical Performance of Non-Concentrator Terrestrial Photovoltaic Modules and Arrays Using Reference Cells, ASTM Standard E1036, New York: American Society of Testing and Materials.

7. x Cyclic Pressure-Load Developmental Testing for Solar Panels, February 1979, JPL/5101-19, Pasadena, CA: Jet Propulsion Laboratory.

8.x Resistance of Photovoltaic Solar Panels to Simulated Hail, April 1978, JPL/5101-62, Pasadena, CA: Jet Propulsion Laboratory. 


\section{APPENDIX A \\ HOT-SPOT ENDURANCE TEST PROCEDURE FOR THIN-FILM MODULES}

\section{A.1 INTRODUCTION}

Field experience indicates that periodic circuit faults must be expected to occur even in highly reliable arrays. Under these fault conditions, it is necessary to ensure that possible hot-spot heating resulting from reverse biasing does not cause propagation of the fault or electrical safety hazards through such mechanisms as solder melting or encapsulant deterioration.

Hot-spot heating occurs in a photovoltaic module when the short-circuit current of a cell becomes lower than the series string operating current. This condition causes the affected cell to go into a reverse-bias condition and absorb power equal to the product of the cell reverse-bias voltage and the string current. The reduced short-circuit current fault condition can be the result of a variety of causes including nonuniform illumination (local shadowing), individual cell degradation caused by cracking or soiling, or loss of a portion of a series-parallel circuit resulting from individual interconnect open circuits. Under this condition, the cell(s) carrying the excess current dissipates power equal to the product of the current and the reversed voltage that develops across the cell(s), which can heat the cell(s) to elevated temperatures.

Techniques to reduce module hot-spot susceptibility include the traditional method of using bypass diodes and a method unique to thin-film cells, limiting the string current by 1 imiting the cell areal size.

The recommended approach is indoor laboratory testing, using artificial light sources, when necessary, to establish the correct illumination level for Type A cells. Indoor testing also eliminates the data scatter resulting from transient wind cooling and variable irradiance levels.

\section{A.2 TEST PROCEDURE}

This test is generally written to be applicable to any of the emerging thinfilm technologies. As such, it includes a series of steps, first to select and instrument appropriate cells for testing, then to determine the hot-spot test levels, and finally to conduct the hot-spot endurance, test.

Step 1. Cel1 Selection and Instrumentation

Perform pretest electrical performance measurements and a pretest electricalisolation test of the module to establish a baseline. Determine and plot the dark reverse-voltage $I-V$ curve for a representative sample of cells (the greater of 10 cells or $35 \%$ of the number of cells, or all cells if fewer than 10 cells) within the test module. This must be done by directly accessing individual cells. The cell's dark characteristics should be determined for reverse voltages from 0 to $V_{L}$ or currents from 0 to $I_{L}$, whichever 1 imit is reached first, 
where

$I_{L}=I_{S C}$ of an average cell at $100 \mathrm{~mW} / \mathrm{cm}^{2}$, nominal operating cel1 temperature (NOCT) or $50^{\circ} \mathrm{C}$ (typical module operating temperature);

$\mathrm{V}_{\mathrm{L}}=\mathrm{N} \times \mathrm{V}_{\mathrm{mp}}$ of an average cell at $100 \mathrm{~mW} / \mathrm{cm}^{2}$, NOCT or $50^{\circ} \mathrm{C}$;

$\mathrm{N}$ = number of series cells per bypass diode or number of series cells per module, whichever is less.

Plotting the family of reverse-voltage $I-V$ curves for the representative sample of cells should produce a graph similar to Figure A-1. The individual curves may be all voltage-limited (Type A), all current-limited (Type B), or a combination of both (as shown). For testing, select 10 individual cells (or all cells if fewer than 10) within the test module from the measured sample, so that no more than three are adjacent and so that at least two untested cells are between any subgroup of cells. At least two cells must be selected from those with the highest shunt resistance, at least two representative of the average, and at least two representative of the lowest.

Provide the test cells with positive and negative electrical leads to allow them to be connected individually to separate power supplies. Hot-spot test leads should be incorporated into a module during the fabrication process and the module should be designated for hot-spot testing. The leads are required to carry full one-sun $\left(100 \mathrm{~mW} / \mathrm{cm}^{2}\right)$ current and must distribute the current into the cells without causing excessive current crowding near the lead attachment or shunting of the cell by damaging the thin-cell metallization.

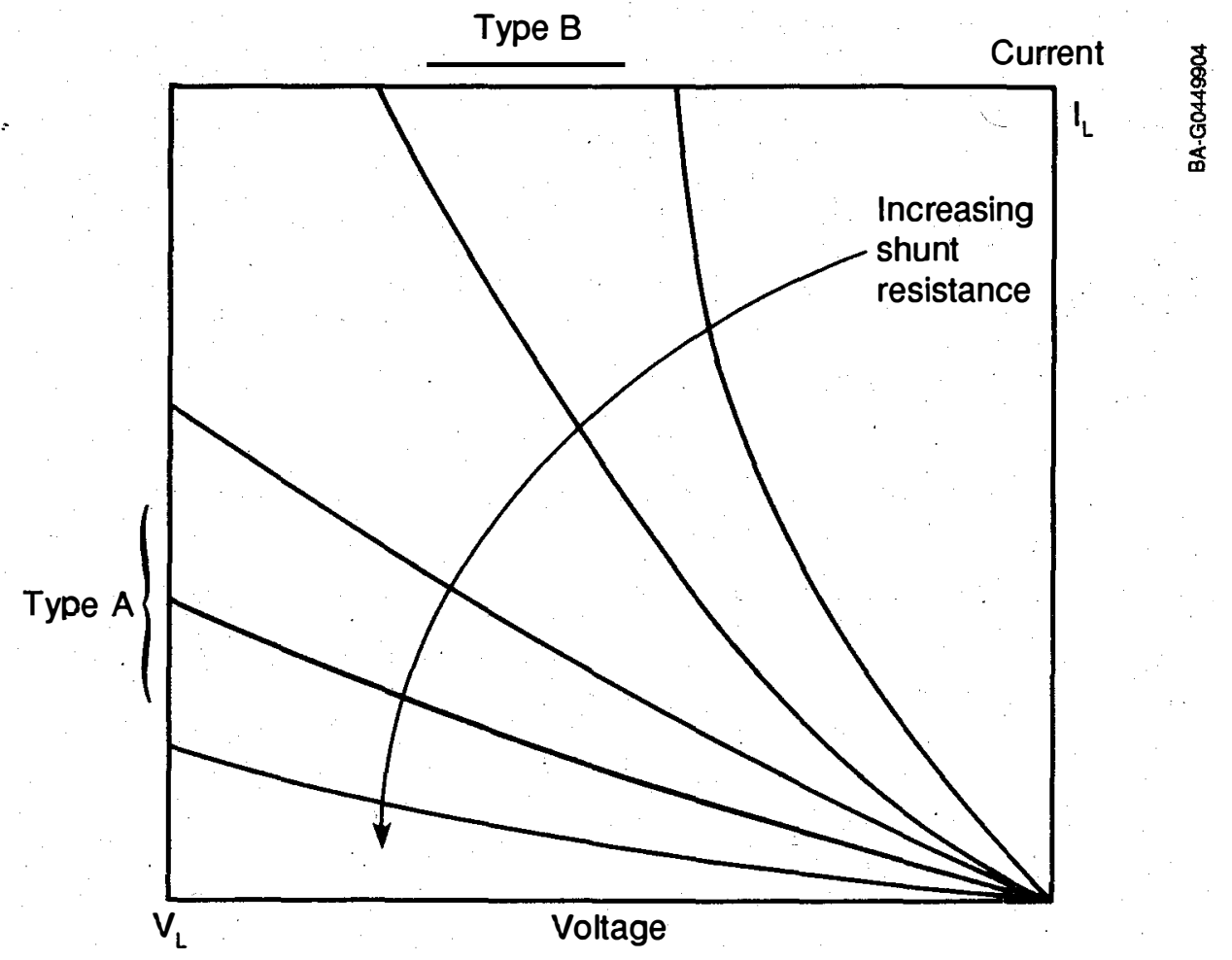

Figure A-1. Typical Reverse-Voltage I-V Plot for a Sample of Cells 
For modules consisting of cells sandwiched between two sheets of glass, the best approach is to obtain special test modules prepared by the manufacturer with a ribbon lead attached along the back of each cell. This lead-attachment technique is also required to distribute the back-bias current along the entire cell surface area because of the poor conductivity of the transparent top conductor.

In the case of modules with parallel strings of cells, parallel current paths around the selected test cells should be eliminated by severing cross ties between the parallel cell strings, including those at the output terminals of the module. Also, the lead attachment should minimize disruption of the cell's heat-transfer characteristics or the hot-spot endurance of the encapsulant system.

\section{Step 2. Selection of Hot-Spot Test Level}

The objective of this portion of the test procedure is to select the level of heating and the corresponding test condition that will stress the module in a manner similar to a severe hot-spot field condition. The severity of the field condition will depend on the array circuit configuration, the array I-V operating point, the ambient thermal conditions, the overall irradiance level, and the previously described characteristics of the affected cells. In particular, whether the cells are Type A or Type B is important.

For Type A Cells. The maximum cell reverse voltage $\left(V_{L}\right)$, the cell illumination level, and the ambient thermal environment are the key parameters. When a module is incorporated into an array source circuit, the maximum reverse voltage imposed on an individual cell can approach the maximum array operating voltage. In this procedure, the array designer presumably has used bypass diodes or other means to 1 imit the reverse voltage on any single module to less than $1 \mathrm{v}$. The test voltage $\left(V_{\text {test }}\right)$ is thus set to yield the maximum reverse voltage that can be applied across a single cell when the test module is shorted with a bypass diode. For type A cells, $V_{\text {test }}$ should be set equal to $\mathbf{N}$ times the average $V_{m p}$ of an individual cell, where $N$ is the number of series cells per bypass giode or the number of series cells per module, whichever is less.

A second key test condition for Type A cells is the illumination level; it directly controls the hot-spot test current ( $I_{\text {test }}$ ) level and, therefore, the power level. As shown in Figure $\mathrm{A}-2$, a unique 1 llumination level corresponds to worst-case power dissipation for any particular Type A solar cell. In the test, the irradiance level on the test cell should be adjusted to achieve this worst-case condition with $I_{\text {test }}$ set equal to the average cell maximum power current at $100 \mathrm{~mW} / \mathrm{cm}^{2}$, NOCT or $50^{\circ} \mathrm{C}$.

A third test condition is the level of the ambient thermal environment. For test purposes, a nominal terrestrial environment shall be created by using an air temperature of $20 \pm 5^{\circ} \mathrm{C}$ and a radiant heating source to achieve a uniform background module cell temperature equal to NOCT or $50^{\circ} \mathrm{C}$.

Type B Cells. Type $B$ cells have a cell shunt resistance so low that the maximum reverse test voltage $\left(V_{\text {fest }}\right)$ is set by the I-R drop across the cell associated with the available current level. In these cells, worst-case 


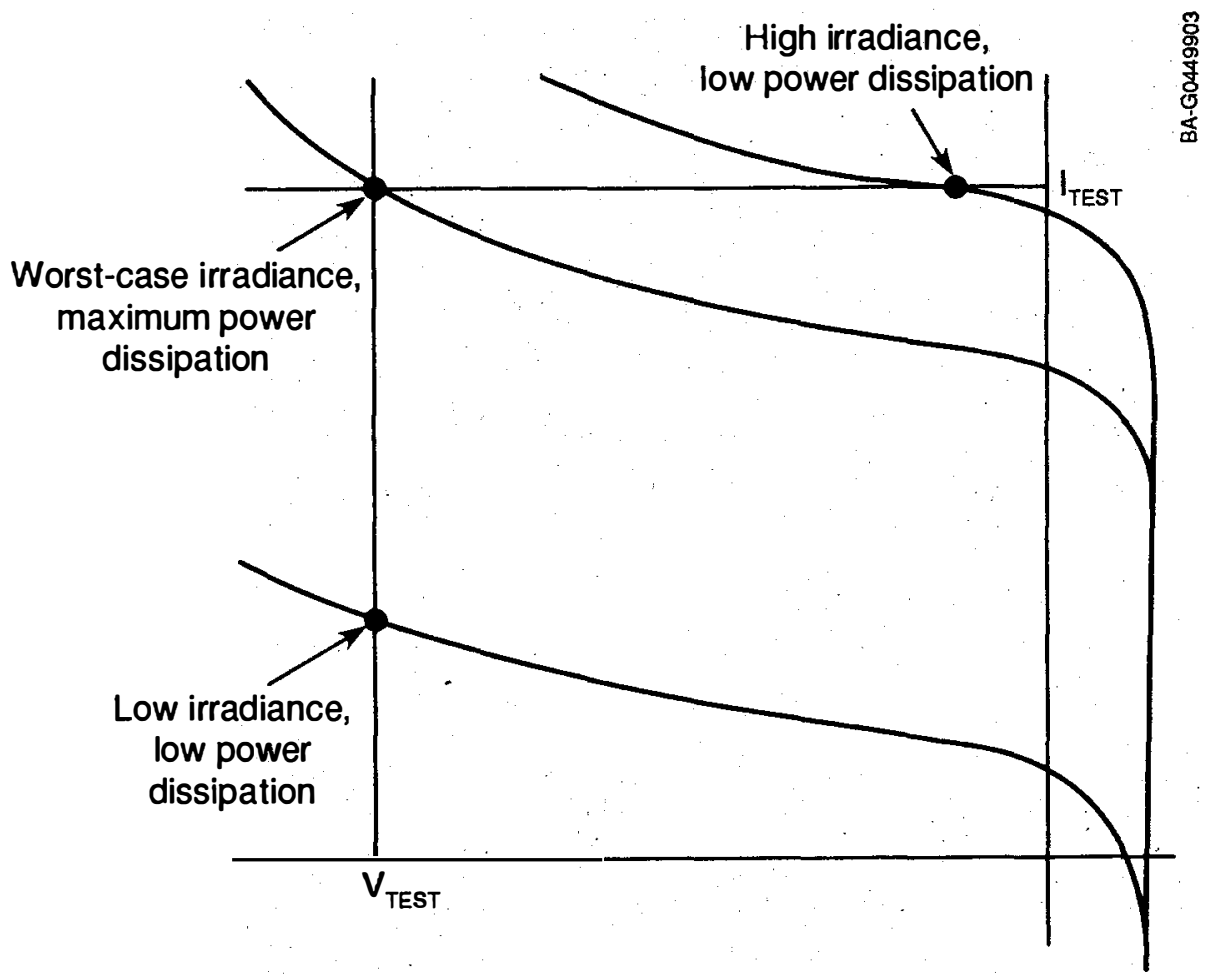

Figure A-2. Effect of Test Cell Illumination Level on Hot-Spot Power Dissipation

heating occurs when the test cell is totally shadowed and the current level is at a maximum. Test conditions for Type $B$ cells shall therefore maintain a cell illumination level of less than $5 \mathrm{~mW} / \mathrm{cm}^{2}$ (to allow for room 1 ighting and an IR heating source) and a current test level ( $I_{\text {test }}$ ) equal to the shortcircuit current of an average cell at $100 \mathrm{~mW} / \mathrm{cm}^{2}$, NOCT or $50^{\circ} \mathrm{C}$.

As with Type A cells, a uniform background cell temperature equal to NOCT or $50 \pm 2^{\circ} \mathrm{C}$ shall be created by using an air temperature of $20 \pm 5^{\circ} \mathrm{C}$, together with a radiant-heating source.

Step 3. Test Execution

Detailed steps for execution of the test involve subjecting the 10 selected test cells (or all cells if fewer than 10) to cyclic hot-spot heating, at the levels determined above, for a period of $100 \mathrm{~h}$ total on-time, as follows.

(1) Connect a separate dual limiting constant-current constant-voltage power supply to each test cell with polarity arranged to drive the cells with reverse voltage. Adjust the voltage and current limits to the $V_{\text {test }}$ and

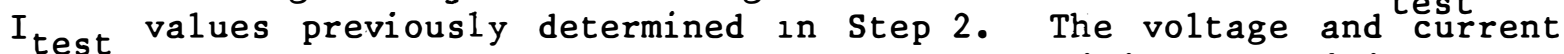
limits should be set before the cells are electrified to eliminate any sensitivity that thin-film cells may have to back-biasing. Even a very short duration of overcurrent or overvoltage may lead to enough degradation of a test cell to render it useless for conducting a hot-spot test. 
(2) Apply an IR radiant-heating source with a visible light contribution below $5 \mathrm{~mW} / \mathrm{cm}^{2}$ to the module front surface and adjust the heating level to achieve a uniform module cell temperature equal to NOCT or $50 \pm 2{ }^{\circ} \mathrm{C}$. The ambient air should be still and at a temperature of $20 \pm 5^{\circ} \mathrm{C}$.

(3) For Type A cells only, arrange an additional light source to illuminate each test cell to the unique level determined in Step 2 (Figure A-2). This is most easily accomplished after the power supply and IR source are turned on by adjusting the illumination level to achieve, simultaneously, both current and voltage limiting at $I_{\text {test }}$ and $V_{\text {test }}$ after equilibrium test conditions stabilize. The illumination source should not contain excessive IR or ultraviolet (UV) irradiance that would lead to abnormal heating or accelerated UV aging. ELH-type tungsten sources have been found to meet this requirement.

(4) Connect the power supplies, IR source, and light sources to an appropriate timer to obtain a cyclic on-off operation with an on-time equal to $1 \mathrm{~h}$ and an off-time sufficient to allow the test cells to cool to within $10^{\circ} \mathrm{C}$ of the ambient air temperature.

(5) Conduct the test until a total of $100 \mathrm{~h}$ of on-time has been accumulated.

(6) During the first cycle, visually inspect the test cells for evidence of arcing. If arcing occurs, monitor the test for at least 10 cycles to ensure that no fire danger exists. Also record the back-bias voltage and current and maintain the current at its desired level. The voltage may decrease, and any such changes should be recorded over the first cycle as they occur. Visually inspect the test cells and adjacent areas of the encapsulation system at approximately 24-h intervals during the test while under bias conditions and upon completion of the 100-h sequence. Identify any evidence of degradation (including delamination, outgassing or blistering of encapsulants), cell cracking, solder melting, or other defects resulting from this test. Also monitor and maintain the back-bias current level at its desired value. Record both back-bias voltage and current at 24-h intervals. Measure the post-test electrical performance of the module for comparison with baseline electrical performance. Perform a post-test electrical-isolation test. 


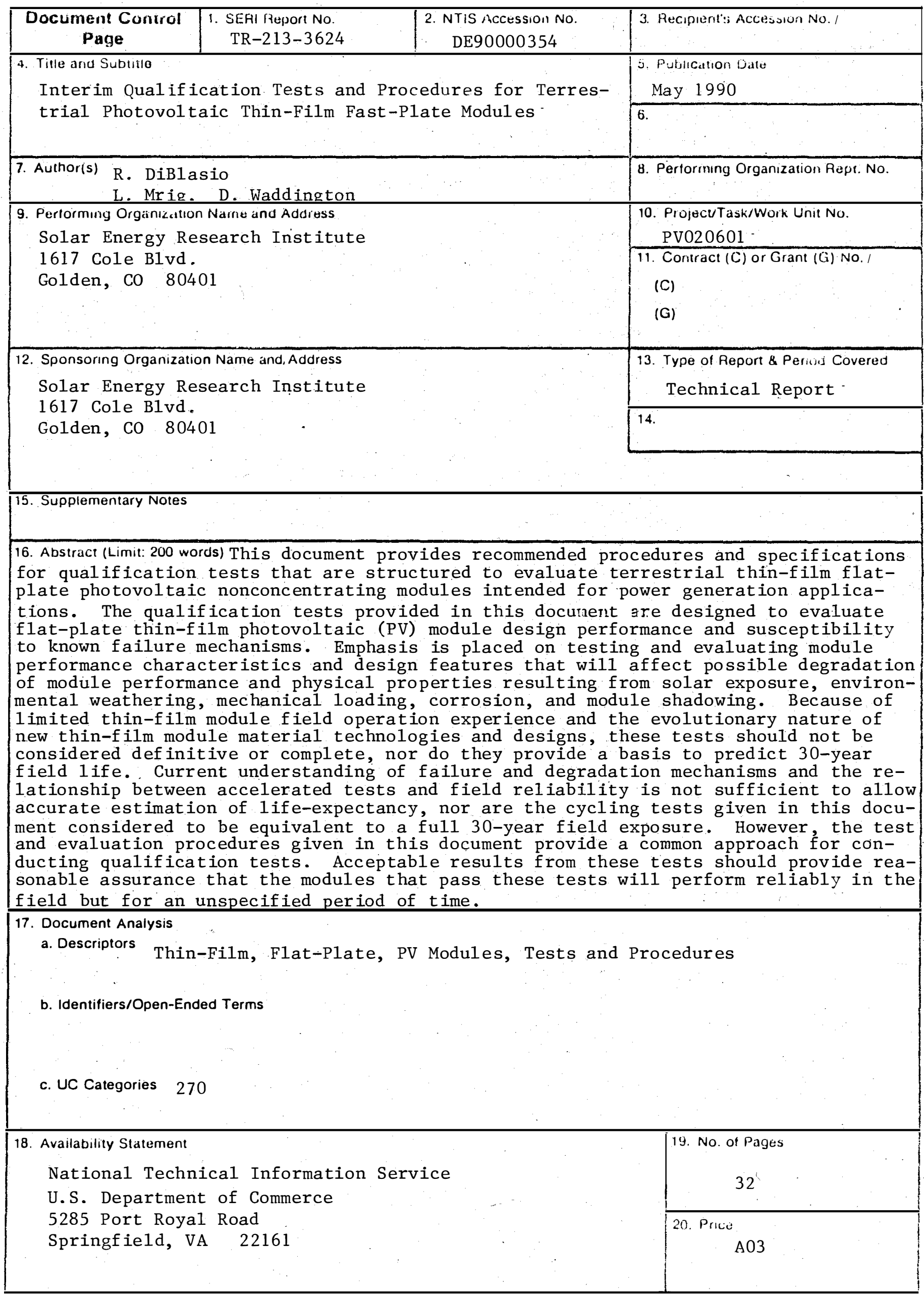

